\title{
Animal Law and Ethics: Reflecting on European, American, and Asian Concepts*
}

University of Zurich, Zurich, Switzerland, July 7 and 8, 2012

\section{Introduction}

Humans and animals are inextricably bound in a complex web of relationships. Many such interactions have ethical relevance and also pertain to the legal sphere. Based on this rationale, the discipline of animal law has increasingly become an area of concern in academic discussion and policy implementation. In addition, it has provided us with various theories that claim animals are the subjects of moral status and the holders of rights. More recently, scholars have begun to ask what we owe to nonhuman animals as members of, and participants in, our political communities. Yet, even though "the animal question" widely influences our legal, ethical, and social systems, in Europe, the discipline of animal law remains in a state of infancy. Animal Law and Ethics, a two-day conference held at the University of Zurich, Switzerland, was one of the many steps that have been taken recently on the initiative of Swiss academics to close this research gap.

The theme of the conference - Reflecting on European, American, and Asian Concepts - represented the goals and spirit of the day. The international conference was intended to draw together academics, practitioners, policymakers, and students to critically examine how a variety of law orders integrate animals' interests and rights into their legal framework, as well as to reflect on fundamental questions regarding the realm of justice and the concept of dignity for animals through the implementation of certain ethical methods of legal philosophy. An exciting group of presenters, featuring some of the most respected voices in the field of animal law and ethics both from Europe and overseas, shared the results of their research, ideas, knowledge, and practical skills regarding the various points of contact between animals, law, and ethics, in addition to discussing the best paths towards further legal protection for animals.

The conference was opened with words of welcome by the organizers, four Swiss scholars: Christoph Ammann, Julia Hänni, Daniela Kühne, and Margot Michel. Margot Michel, Deputy Professor and Research and Teaching Associate at the University of Zurich, used her introductory talk to address the simultaneity of persistence and progress in animal welfare laws and their implementation, the limitations of current conceptions of animal protection, as well as the public concern and protests vis-à-vis the growing number of mistreated animals and the obvious failure of the legislation and current enforcement mechanisms to prevent such abuse.

This Report aims to give an overview of the presentations given at the conference and to offer some concluding remarks. 1

\section{Presentations}

The first presentation by Christine M. Korsgaard from Harvard University dealt with Immanuel Kant's moral philosophy and its implications for the animal rights movement. While Kant's views are usually considered detrimental to the moral claims and legal rights of nonhuman animals, Korsgaard argued

\footnotetext{
* A shorter version of this conference report appeared in Schweizer Zeitschrift für Biomedizinische Ethik, Bioethica Forum 3/2012

${ }^{1}$ For further information on the field see Michel, M., Kühne, D., and Hänni, J. (ed.) (2012). Animal Law: Developments in the $21^{\text {st }}$ Century. Zurich/St. Gallen, Switzerland: DIKE.
} 
that they nevertheless capture something about our own existential situation that proclaims our fellowship with the other animals. As the laws of reason are always our human laws, we are precluded from knowing whether the world as it is in itself conforms to them or not. Nevertheless, Korsgaard explained, Kant's theories give us grounds to hope that we can make the world a better place that meets our standards, i.e., a world that is rational and good. We share with other creatures the fate of living in this world, which gives both of us no guarantees, and we all try to make a home here. This is why, Korsgaard concluded, both our fates matter, and we should concede the moral claims of nonhuman animals and protect these claims as a matter of legal rights.

The second presentation by Beat Sitter-Liver from the University of Bern focused on the concepts of dignity of the creature and the principle of justice. Sitter-Liver discussed the differences in the constitutional concepts of human and animal dignity and then turned to the question of whether nonhuman animals could and should be regarded as members of our human community of justice. Against the background of fundamental equality of humans and animals, Sitter-Liver stressed that there is nothing that precludes nonhuman animals from having natural and moral rights, and from being members of our community of justice as long as we want it. He argued that it is nothing other than a basic question of justice that we should want to include nonhuman animals into our community of justice because the alternative - their exclusion from this community - would amount to arbitrariness and injustice, keeping in mind that we constantly make use of them in order to accomplish our very own objectives.

In a nuanced and novel approach, Will Kymlicka, from Queen's University in Kingston, Canada, offered a new agenda for the theory and practice of animal rights. Whereas the traditional animal rights theory focuses on the intrinsic capacities or interests of animals, and the moral status and moral rights that these intrinsic characteristics give rise to, Kymlicka shifted the debate from the realm of moral theory and applied ethics to the realm of political theory. In his presentation, he focused on the relational obligations that arise from the varied ways that animals relate to human societies and institutions. Introducing a "political animal," Kymlicka argued that different types of animals stand in different relationships to human political communities. Domesticated animals should be seen not as property but as full-fledged members of human-animal mixed communities, thus having a claim to a "package" of rights. Wild animals, by contrast, form their own sovereign communities. According to Kymlicka, they are entitled to protection against human-instigated threats, such as the pollution of water or air, in order to safeguard their ongoing self-government. Wild animals that live in the midst of our communities but are not domesticated inhabit an in-between position and deserve fundamental respect. Kymlicka emphasized that it makes no difference that none of these animals advocate for such respect, because humans routinely extend similar rights to members of their own species who likewise cannot advocate for them (e.g., infants or the mentally feeble).
Turning to the U.S.-American perspective, David Favre from the Michigan State University introduced the audience to his concept of "animals as living property." In U.S. legal doctrine, the standard discussion lists three basic categories of property - real property, personal property, and intellectual property. However, unlike other property, animals are alive and have interests independent of the humans who own them. In order to integrate these interests in a more comprehensive way into the American legal system, Favre argued in favor of the creation of a fourth category of property, the so-called "living property" that is hoped to trigger a focused scholarly consideration of animal-related issues, resulting in a new list of legal rights for at least some animals. Furthermore, Favre addressed the controversial topic of the "use" of animals. He argued that while it is in his view not ethically forbidden to use animals, he called for a respectful use while at the same time acknowledging the difficulty in determining which uses might be deemed respectful. Addressing the law's minimum protection of animals' interests, Favre further highlighted the importance of responsible animal ownership and the ethical treatment of animals by individual human beings.

With the presentations by Pamela Frasch and Kathy Hessler from Lewis \& Clark Law School's Center for Animal Law Studies in Portland the discussion turned to the practical side of education and legislation in the U.S. Pointing to the impressive 135 American Bar Association-accredited schools that presently offer at least one animal law course - compared to only 15 in the year 2000 - Frasch illustrated the rapid development of the academic discipline in the U.S. Additionally, the desire to become an animal law attorney had been identified as the sole reason for attending law school by a growing number of students. The Center for Animal Law Studies, of which Frasch is Executive Director, hosted the first Animal Rights Law Conference in 1981 and currently offers a total of 35 animal law courses. Hessler for her part stressed the importance of the cross-functional collaboration of academics, policy makers, attorneys, veterinarians, and others in developing a more comprehensive set of legal rules for animals.

Raj Panjwani, Senior Counsel at the Supreme Court of India, presented Indian case studies on constitutional clauses pertaining to animals. Turning to article $51 \mathrm{~A}(\mathrm{~g})$, which makes the compassion for living creatures a fundamental duty of all Indian citizens, Panjawani gave a brief overview of a range of practical legal implications of this constitutional clause, such as the ban on using animals like bears or tigers as performing animals in circuses. He explained how circus owners challenged this ban, arguing that it invaded their fundamental right to carry on trade. The Supreme Court of India had to consider the issue and decided that no person had the right to carry on trade that inflicts unnecessary pain or suffering to animals. Moreover, it stated that the definition of "trade" did not include obnoxious activities like the exhibition of wild animals for entertainment. Panjwani, in conclusion, identified some issues that might become relevant under the constitutional compassion clause in the future.

Zoos are also high on the agenda of Egypt's animal rights activists. Kristen Stilt, from the Northwestern University School 
of Law in Chicago, addressed some of the highly topical issues with which Egypt's newly reinvigorated animal rights movement plans to deal: overcrowded zoos, badly managed slaughterhouses, cruel live importation of sheep and cattle, appalling conditions in pet shops, mismanagement and corruption, and, last but not least, the lack of laws and enforcement of existing legislation. Regarding stray dogs, Stilt also brought a decidedly cultural dimension into the conference by reporting problems with Trap/Neuter/Release (TNR) Programs that stem from the widespread notion that dogs are "impure" according to certain Islamic ahadith (traditions, i.e., sayings of the Prophet Muhammad).

The last presentation analyzed the achievements and deficiencies of Swiss animal law under a comparative perspective. Gieri Bolliger, from the Foundation for the Animal in the Law, first presented an overview of the legal status of animals and their protection under Swiss constitutional and substantive law and compared the outcome to other jurisdictions worldwide. Notwithstanding constitutional guarantees of the dignity of the creature and the protection of the animal's dignity in the Animal Protection Law, Swiss legislation does not, for instance, protect animals' lives per se - contrary to neighboring legislation in Austria and Germany. Bolliger further explained that even though Switzerland has some of the most progressive animal welfare legislation, there still is room for improvement with regard to legal norms, their implementation, and enforcement.

The following speakers also contributed excellent presentations: Anne Peters from the University of Basel ("Liberté, Égalité, Animalitê": Observations of Comparative Legal History of the Animal Welfare Movement and the International Human Rights Movement), Tanja Domej, University of Zurich (Animal Law Enforcement - Existing Models and Possible Ways Forward), Eva Maria Maier, University of Vienna
(Do We Need a Paradigm Shift in European Animal Protection?), Jean-Pierre Marguénaud, Université de Limoges (L'animal dans la jurisprudence de la Cour européenne des droits de l'Homme).

\section{Concluding remarks}

The first Swiss Animal Law Conference was a visible success. The invited speakers had outstanding expertise in the field and a great enthusiasm for promoting discussion and the conference provided excellent educational and networking opportunities for all participants.

The conference papers allow for some general observations regarding the research area of animal law. First, they showed how deeply legal questions pertaining to animals are entrenched in different societies. Moreover, while the speakers represented various legal traditions, the relationship between humans and nonhuman animals, as well as the significance of an overarching community of the two groups, appeared as recurring themes of the presentations. Second, it illustrated the vibrancy of the research field of animal law and showed how it allows researchers to deal with more innovative concepts than other legal domains. Third, it became quite clear that the research area of animal law in Europe is soon bound to leave its infancy behind.

Eveline Schneider Kayasseh, Dr jur. Senior Research Assistant and Project Manager, Center for Islamic and Middle Eastern Legal Studies (CIMELS), University of Zurich, Switzerland 